\title{
Implicit Theories of Ability of Grade 6 Science Students: Relation to Epistemological Beliefs and Academic Motivation and Achievement in Science
}

Jason Chen

College of William \& Mary, jachen@email.wm.edu

Frank Pajares

Emory University

Follow this and additional works at: https://scholarworks.wm.edu/articles

Part of the Cognitive Psychology Commons, Educational Psychology Commons, Junior High, Intermediate, Middle School Education and Teaching Commons, and the Science and Mathematics Education Commons

\section{Recommended Citation}

Chen, Jason and Pajares, Frank, "Implicit Theories of Ability of Grade 6 Science Students: Relation to Epistemological Beliefs and Academic Motivation and Achievement in Science" (2010). Articles. 49. https://scholarworks.wm.edu/articles/49 


\title{
RUNNING HEAD: IMPLICIT THEORIES AND EPISTEMOLOGICAL BELIEFS
}

Implicit Theories of Ability of Grade 6 Science Students:

Relation to Epistemological Beliefs and Academic Motivation and Achievement in Science

\author{
Jason A. Chen \\ Frank Pajares \\ Emory University
}

Frank Pajares, my dear mentor and the "One I Remember" passed away on January 14, 2009, months before this manuscript was submitted. The lead author would like to thank Timothy Urdan for the timely and invaluable assistance he provided in Frank Pajares's absence. Many thanks also go out to Barbara Hofer and three anonymous reviewers for their helpful and insightful comments on an earlier version of the manuscript. Finally, the lead author would like to thank the teachers, administrators, students, and research assistants who took time out of their busy days to make this study possible.

Information contact:

Jason A. Chen

Division of Educational Studies

1784 N. Decatur Rd., Suite 240

Emory University

Atlanta, GA 30322

Voice: (404) 727-2626

Fax: (404) 727-2799

Email: jchen04@emory.edu 


\section{RUNNING HEAD: IMPLICIT THEORIES AND EPISTEMOLOGICAL BELIEFS}

Implicit Theories of Ability of Grade 6 Science Students:

Relation to Epistemological Beliefs and Academic Motivation and Achievement in Science 


\begin{abstract}
We investigated (a) the associations of implicit theories and epistemological beliefs and their effects on the academic motivation and achievement of students in Grade 6 science and (b) the mean differences of implicit theories, epistemological beliefs, and academic motivation and achievement as a function of gender and race/ethnicity $(\mathrm{N}=508)$. Path analysis revealed that an incremental view of ability had direct and indirect effects on adaptive motivational factors, whereas fixed entity views had direct and indirect effects on maladaptive factors. Epistemological beliefs mediated the influence of implicit theories of ability on achievement goal orientations, self-efficacy, and science achievement. Results are discussed in relation to Dweck and Leggett's (1988) social-cognitive theory with a focus on middle school science. Keywords: Implicit theories; Epistemological beliefs; Middle school students; Science; Academic motivation; Gender; Ethnicity.
\end{abstract}


Implicit Theories of Ability of Grade 6 Science Students:

Relation to Epistemological Beliefs and Academic Motivation and Achievement in Science A long line of research has consistently shown that students' beliefs are as powerful predictors of achievement as factors such as previous achievement or standardized test scores (Bandura, 1997; Dweck \& Leggett, 1988; Hong, Chiu, Dweck, Lin, \& Wan, 1999; Pajares \& Kranzler, 1995; Robins \& Pals, 2002; Stipek \& Gralinsky, 1996). What beliefs facilitate academic success? One that has received much attention in the past two decades is students' implicit theories of ability. According to Dweck and Leggett (1988), students adopt one of two different personal "theories" about the nature of ability. Some students adopt what is called the entity view of ability whereas others espouse an incremental view. Compared to students with an incremental view, students with an entity view are more inclined to believe that abilities are characteristics or traits that a person possesses to varying degrees and that these abilities are a relatively static entity. In contrast, students who hold an incremental view of ability are more likely than their entity theory peers to believe that abilities are an increasable and controllable quality.

Decades of research have shown that implicit theories of ability play a key role in students' academic motivation and achievement. These beliefs, as we discuss later, take on a heightened level of importance particularly during the early adolescent years and during periods of transition, such as from elementary school to middle school (Blackwell, Trzesniewski, \& Dweck, 2007). Dweck and her colleagues have shown that implicit theories of ability influence students' goal orientations, their beliefs about what effort and failure mean, the strategies they employ on academic tasks, and ultimately, their academic achievement (Blackwell et al., 2007; Dweck \& Leggett, 1988; Hong, Chiu, Dweck, Lin, \& Wan, 1999; Robins \& Pals, 2002). Because 
implicit theories have been shown to be related to so many motivational constructs and to academic achievement, implicit theories of ability sit at the heart of Dweck's social cognitive model and create a "meaning system" that can lead students down two different motivational and developmental paths (Hong, et al., 1999). Therefore, while students who espouse a fixed entity view of ability may be just as capable and achieve at the same levels as those who hold an incremental theory of ability, the beliefs they hold about the nature of intellectual ability may result in significantly different academic outcomes, especially when students are presented with tough challenges and setbacks.

As Table 1 illustrates, students who adopt an incremental theory of ability are likely to adopt learning goal orientations and, regardless of confidence, are likely to display adaptive behavioral patterns. In contrast, students who hold an entity theory of ability are more apt to hold performance goal orientations, and only when coupled with high confidence are they likely to display adaptive behavioral patterns. One note should be made, however. In Dweck's model (Dweck and Leggett, 1988), confidence is defined as how certain students are about their own intellectual abilities. For example, sample items from the "confidence" measure include the following, where participants rate the degree to which they agree or disagree with these statements: "I usually think I'm intelligent;" or "I feel pretty confident about my intellectual ability." This definition differs markedly from a well studied construct that often gets mistakenly labeled as confidence - self-efficacy. Self-efficacy is defined by Bandura (1997) as one's perceived capabilities to learn or accomplish tasks at designated levels of performance. As we point out later, self-efficacy has rarely been used in studies investigating its role in Dweck and Leggett's social cognitive model. 
According to Dweck and Master (2008), an entity view of ability does not promote taking active charge of learning. An incremental view of ability, on the other hand, promotes active engagement in regulating students' own motivation and learning. Ommundson (2003) found that students with an incremental view of ability in a physical education course were more likely to change strategies when confronted with obstacles, redoubled their efforts when they encountered difficulties, and used deeper processing than did their entity theory peers. According to Dweck and her colleagues, those who espouse an incremental view of ability not only do more to manage their learning and motivation, but also are much more willing to find and address deficiencies in their learning (Hong et al., 1999). The researchers found that entity theory students who performed poorly on a task were significantly less likely than incremental theory students to take a remedial course to address deficiencies and improve future performance. Thus, as Dweck and Master argued, students who believe that ability can be acquired put forth the effort to make it happen. When they believe, on the other hand, that ability is something people either have or do not have, they do far less to ensure their success.

Although there have been many studies addressing the link between implicit theories of ability and self-regulation, no studies have been done addressing whether implicit theories of ability are related to self-efficacy for self-regulation. But beliefs about whether individuals can regulate their own learning are of critical importance, as Bandura (1997) argued: "Neither cognitive processing skills nor metacognitive skills will accomplish much if students cannot get themselves to do academic assignments. A strong sense of efficacy to regulate one's motivation and instructional activities undergirds belief in one's academic efficacy and aspirations" (p. 231).

Indeed, researchers have found that students' self-efficacy for self-regulated learning is related to motivation and achievement in many subject areas, including language arts, 
mathematics, and science, and for students of all levels of schooling. Self-efficacy for selfregulation has been shown to be positively related to academic self-concept, self-efficacy, value of school, mastery goal orientations, and achievement outcomes such as essay writing and mathematics problem solving. Self-efficacy for self-regulation is also negatively related to anxiety and performance-avoid goal orientation (Pajares, 1996; Pajares, Britner, \& Valiante, 2000; Pajares \& Graham, 1999; Pajares, Miller, \& Johnson, 1999; Pajares \& Valiante, 1999, 2001). Clearly, self-efficacy for self-regulation plays a pivotal role in the development and sustenance of students' motivation to pursue an activity, especially in the face of hardships. Implicit theories of ability have also been theorized to be related to epistemological beliefs (Bråten \& Olaussen, 1998, 2005; Bråten \& Strømsø, 2004; Hofer \& Pintrich, 1997). Epistemological beliefs have received considerable attention in the past decade and describe people's beliefs about the nature of knowledge and knowing. Epistemology, as a philosophical endeavor, is concerned with "the origin, nature, limits, methods, and justification of human knowledge" (Hofer, 2002, p. 4). However, epistemological beliefs investigated from a psychological and educational perspective deal with how people form their conceptions of knowledge and knowing, and how people utilize these conceptions to understand their surroundings. Although individuals unconsciously hold these beliefs about knowledge and knowing, they are still influenced by them.

\section{Defining Epistemological Beliefs}

What do epistemological beliefs consist of? Although there are some variations in how the construct is defined, there are four dimensions outlined as the core components of epistemological beliefs (Hofer \& Pintrich, 1997). Concerning the nature of knowledge, individuals hold beliefs about the certainty of knowledge, which represents the degree to which 
one sees knowledge as fixed or fluid. The more naïve view about the certainty of knowledge represents a view that absolute truth exists with certainty. The more sophisticated view reflects the belief that knowledge is more tentative and is constantly evolving. The second dimension concerning the nature of knowledge deals with beliefs about the simplicity of knowledge, which represents the degree to which one sees knowledge as either concrete, knowable, and isolated facts (the more naïve view), or as relative, contextual, and interrelated concepts (the more sophisticated view).

Concerning the nature of knowing, individuals hold beliefs about the source of knowledge, which represents the belief that knowledge either originates from outside of the self and within external authorities (the more naïve view), or that knowledge is actively constructed from one's personal experiences (the more sophisticated view) such that the individual becomes the maker of meaning rather than just the receiver of meaning. Finally, individuals hold beliefs about the justification of knowing, which concerns how individuals evaluate knowledge claims, make use of evidence to justify what they believe, and what they believe about the role of authority and expertise in making knowledge claims. As students mature in their abilities to evaluate evidence and justify what they believe, they progress from a more naïve stage whereby knowledge is justified by acclimating to the views of authority figures, to more sophisticated beliefs whereby knowledge is justified be reasoning and by thoughtful use of expert opinions.

Not only are epistemological beliefs multidimensional, as illustrated above, but they are also domain specific (Buehl \& Alexander, 2001; Hofer, 2000; Hofer, 2006; Muis, 2006). Hofer (2006) has argued that domain specific measures should be used in discovering how epistemological beliefs may be related to other aspects of cognition and learning. In the present study, therefore, we conceptualize epistemological beliefs in the context of science instruction. 
This conceptualization is in line with Hofer and Pintrich's (1997) hypothesized four core dimensions. These four dimensions can then be categorized under the two broader areas that represent the core of the construct: The nature of knowing and the nature of knowledge. The source and justification dimensions fall under Hofer and Pintrich's category labeled nature of knowing. The source dimension we used is conceptualized as the belief that scientific knowledge either resides outside of the self with experts in science (the more naïve view), or that scientific knowledge can be personally constructed (a more sophisticated view). In science, justification of knowledge claims involves the ways in which students use experimental evidence and data to support their claims. Beliefs about justification range from more naïve beliefs indicating that the purpose of science experiments is to do projects and activities, to more sophisticated beliefs that experiments are used to generate data, which are then used to explain and test phenomena.

The two dimensions called the certainty of scientific knowledge and the development of scientific knowledge fall under Hofer and Pintrich's (1997) category called the nature of knowledge. The certainty dimension, as conceptualized in the context of science, represents the belief that questions posed in science either have only one right answer (a more naïve view), or that questions can have more than one correct answer (a more sophisticated view). The development dimension represents the belief that science is either a static body of knowledge (more naïve belief), or that science is constantly evolving and that ideas and theories can change if scientists are presented with new evidence (a more sophisticated view). Although beliefs about the nature of knowledge are typically conceptualized as certainty and simplicity (Hofer, 2000; Hofer \& Pintrich, 1997), the conceptualization employed in the current study was also used by Conley et al. (2004). 
Although the above four dimensions represent the core components of the construct, Schommer (1990) has developed a conception of epistemological beliefs that incorporates some of these core components as well as what Hofer and Pintrich (1997) call "peripheral constructs," which may be related to the four core dimensions. Schommer's model of epistemological beliefs includes factors that, stated from the naïve perspective, are called fixed ability, quick learning, simple knowledge, and certain knowledge. Although the last two are core components of the construct, the first two are more in line with beliefs about learning and intelligence. Hofer and Pintrich (1997) argued, "although beliefs about the nature of knowledge and the nature of intelligence or ability may be correlated with one another, they are separate constructs, and it seems more useful and theoretically fruitful to keep them separate” (p. 109).

According to Hofer and Pintrich, the Fixed Ability dimension does not follow the patterns of the other dimensions of epistemological beliefs. In fact, this dimension is more in line with Dweck and Leggett's (1988) implicit theories of ability, which are not typically considered part of the construct of epistemological beliefs since implicit theories deal with the nature of ability as a personal, psychological trait or characteristic. For this reason, beliefs about ability do not necessarily deal with the nature of knowledge and knowing. But how might these two constructs be related? Hofer and Pintrich posited that the four dimensions [of epistemological beliefs] should be considered the core of an individual's theory, while the other beliefs about learning, teaching, and intelligence may be related to the core dimensions but are peripheral to an individual's theory ... It may be that the more peripheral ideas about learning and teaching are developmental precursors to the core ideas about epistemology. (p. 119) 
Dweck, Chiu, and Hong (1995) also provide some clues as to how implicit theories of ability and epistemological beliefs may be related. They argued that an entity theory generally "portrays a social world that is relatively stable and predictable. Thus, compared to incremental theorists, who subscribe to a world view that is more dynamic and complex, entity theorists may believe closure is more easily attainable" (p. 281). They also argued that "because lack of structure is antithetical to the orderly relations implied by a fixed reality, entity theorists may also have a higher personal need for structure in the relevant domain than do incremental theorists" (p. 281). Implicit theories, then, are hypothesized to give rise to epistemological beliefs, which are themselves posited to influence academic motivation and achievement. Indeed, Dweck, Chiu, and Hong posited that an incremental view represents a view of the world that is dynamic and may result in a lower degree of certainty in making predictions. They then hypothesized that, compared to those who espouse an entity theory, incremental theorists may need to engage in more complex and effortful analysis to attain that level of certainty in making predictions. This static versus dynamic view of reality is inherent in the epistemological beliefs construct. Belief in the certainty of knowledge, for example, is characterized by how fluid or static knowledge is and whether absolute truth exists with certainty. Implicit theories, then, might be what Dweck, Chiu, and Hong call core assumptions that foster a framework for how students view their surroundings.

\section{Implicit Theories and Epistemological Beliefs in Middle School Science Classrooms}

Middle school science classrooms provide researchers with a valuable opportunity to investigate the development of implicit theories and of epistemological beliefs, since curriculum goals in such settings often stress the importance of aiding students to achieve scientific literacy (e.g., American Association for the Advancement of Science [AAAS], 1993; National Research 
Council [NRC], 1996). And although scientific literacy does not have one agreed-upon definition, many of the reform documents in science education emphasize aspects that are included in types of science epistemological beliefs (e.g., scientific knowledge is tentative and subject to change and scientific knowledge is empirically based) (AAAS, 1993; NRC, 1996).

In addition, the adolescent years are generally ones that involve rapid developmental changes and a transition to more challenging educational demands (Eccles, Midgley et al., 1993; Montemayor, Adams, \& Gullotta, 1990; Wigfield, Byrnes, \& Eccles, 2006). Middle school students typically experience much more competition and social comparisons than do elementary school students (Eccles, Midgley et al., 1993). As a result of the transitions adolescents have to negotiate, many middle school students experience a decline in academic achievement and school engagement (Eccles, 2004; Wigfield, Eccles, \& Pintrich, 1996). It is also thought that young children before the ages of 11 or 12 operate almost exclusively in an incremental view of ability, ascribing to the belief that smart people try hard, and that trying hard makes you smart (Dweck, 1999; Stipek, 2002). When students transition to middle school there tends to be a shift toward the belief that those who succeed without working hard must be the smart ones, and if someone has to put forth a considerable amount of effort it must be a sign of some deficit in ability. During adolescence this type of belief is thought to influence middle school students' academic motivation (Anderman \& Maehr, 1994). Examining students in middle school science classrooms can therefore provide important insights into the development of students' beliefs about science ability and about scientific knowledge.

\section{Gender and Race/Ethnicity}

It is possible that there are some group differences in implicit theories of ability and epistemological beliefs. Some have suggested that girls may endorse more of a fixed view of 
ability than do boys (Dweck, 1999; Dweck, 2002; Stipek \& Gralinsky, 1991). As regards race/ethnicity, some evidence exists showing that despite generally scoring lower on academic achievement than their White and Asian American peers, African American students hold stronger incremental views of their ability. Good, Aronson, and Inzlicht (2003) also demonstrated that when presented with an incremental message intervention, African American students responded more positively than did their White peers. Thus teaching students an incremental theory may have different effects on academic achievement depending on the students' race/ethnicity.

Although much research has been conducted examining gender differences in epistemological beliefs (e.g., Baxter Magolda, M. B., 1992; Belenky et al., 1986; Clinchy et al., 1985), some have argued that there are no important gender differences in the development of epistemological beliefs (Pintrich, 2002). Pintrich argued that when epistemological beliefs are operationalized to incorporate multiple, independent dimensions, as opposed to more holistic developmental models, no gender differences should arise in epistemological beliefs. Therefore, when students are asked to answer questions that focus on one particular domain of epistemological beliefs, there are no differences between boys and girls. Moreover, boys and girls seem to develop in their epistemological beliefs at about the same rate. Nevertheless, gender may play an important role in epistemological reasoning in ways that are undetectable. For example, Belenky et al. (1986) described "connected knowing" as a more feminine approach to knowing and learning. The approach advocates a model of teaching whereby teachers are "participant-observers" who model their thinking processes aloud to the class and aid their students in building knowledge not through competing for the "right" answer, but by building consensus (Hofer \& Pintrich, 1997). However, this connected way of knowing might indeed be 
associated more with female students, but if male students identified with such a way of knowing it may mean something quite different for them than for female students.

\section{Statement of the Problem}

Dweck (2002a) argued that "much of society is stubbornly wedded to the idea that accomplishment, especially outstanding accomplishment, is about endowment. We ignore the fact that Mozart, Darwin, Michael Jordan, and Tiger Woods practiced feverishly and singlemindedly for years, and instead believe that they were simply born with one-in-a-million ability" (p. 39). Students who adopt an entity theory of ability are more likely than are their incremental peers to believe that great accomplishments are the products of inherited endowments, therefore possibly weighting natural talent and ability over other important motivational constructs. Although there is ample research concerning implicit theories and their relationship with both achievement goal orientations and academic achievement (Aronson, Fried, \& Good, 2002; Blackwell et al., 2007; Dweck \& Leggett, 1988), few researchers have examined the relationship between implicit theories and other self-beliefs that have also been prominent in the area of academic motivation, such as epistemological beliefs and self-efficacy. Although Bråten and Olaussen (1998) studied the relationship between self-efficacy and implicit theories of ability in an academic setting, they used a global measure of self-efficacy with high-achieving Norwegian college students. Bandura (1997) argued that "self-efficacy beliefs should be measured in terms of particularized judgments of capability that may vary across realms of activity, different levels of task demands within a given activity domain, and under different situational circumstances" (p. 6). Scores provided by global measures of self-efficacy beliefs are of limited value in predicting specific academic outcomes. Therefore, academic outcomes in a particular subjectarea should be predicted using scales tailored to that same area (Pajares \& Schunk, 2001). 
Studies demonstrating the relationship between implicit theories of ability and Dweck's notion of "confidence" typically show that confidence moderates the influence of implicit theories and achievement goal orientations on achievement relevant outcomes (Dweck \& Leggett, 1988). Some have called this hypothesis into question, however. Tabernero and Wood (1999) argued that "a different causal role for self-efficacy is suggested by Dweck and her colleagues, who argue that the impacts of conceptions of ability on behavior are moderated by an individual's perceived present ability, or self-efficacy" (p. 109). Tabernero and Wood hypothesized, instead, that implicit theories of ability exert their influence on academic outcomes through the mediating influence of self-efficacy beliefs. That is, implicit theories of ability directly influence self-efficacy, which itself influences academic outcomes. In other words, implicit theories of ability influence academic outcomes by first influencing self-efficacy. In contrast, according to the moderator hypothesis, self-efficacy operates independently of implicit theories of ability to affect academic outcomes. Similar results were found by Cury, Elliot, Da Fonseca, and Moller (2006).

We note, however, that "confidence" has been defined in different ways by different researchers. Tabernero and Wood defined confidence as self-efficacy. Cury et al. (2006), however, defined confidence in the same way Dweck and Leggett (1988) defined it. More research needs to be conducted such that the notion of confidence is clearly defined and operationalized in such a way that the measure assesses the appropriate achievement-related outcomes. Few studies have been conducted examining the role of self-efficacy in Dweck's social-cognitive model, and none have been conducted in the context of middle grades science classes. 
Finally, according to Molden and Dweck (2006) and Hofer (2000) there is a need to examine possible linkages between implicit theories, epistemological beliefs, and students' academic motivation and achievement. Specifically, these theorists hypothesized that students' implicit theories may be precursors to epistemological beliefs, which are themselves posited to influence academic motivation constructs that have themselves been extensively investigated. These constructs include achievement goal orientations, self-efficacy, self-regulation, and selfconcept. To date, there has been no empirical evidence to support the posited relationship between implicit theories of ability and epistemological beliefs, nor the relationship between these constructs and the aforementioned motivation constructs or academic achievement variables.

\section{Significance}

By now, much empirical evidence has amassed showing the importance of implicit theories of ability and epistemological beliefs to academic motivation and achievement. Despite Hofer and Pintrich's (1997) suggestion that implicit theories of ability may serve as precursors to the four core dimensions of epistemological beliefs, no research has been conducted to support this hypothesis. Therefore, the present study has theoretical significance in that we sought to refine and extend the theoretical tenets of implicit theories of ability and epistemological beliefs by testing hypothesized relationships that have yet to be empirically supported.

Research investigating the relationships between beliefs about ability and beliefs about knowledge and knowing is also of practical significance to science teachers. If, as Dweck and Leggett (1988) suggested, students who hold a fixed view of their abilities are likely to develop oversimplified and naïve views about knowledge, teachers will want to encourage students that with effort their abilities can improve. In the area of science, in particular, there has been a 
concerted effort by science educators to explicitly encourage students to think critically about knowledge claims in science and the processes by which scientists arrive at conclusions. Despite these efforts, high school students still possess naïve beliefs about scientific knowledge (e.g., scientific experimentation is done simply to prove what we already know, rather than a purposeful activity in which scientists try to generate and test their hypotheses) (Elder, 2002; Solomon, Duveen, \& Scott, 1994). But students are ill-served when they approach learning situations from a naïve perspective of scientific knowledge or from a fixed entity view of science ability. Both of these perspectives have been consistently linked to maladaptive motivational patterns of behavior, such as performance-avoid goal orientations, maladaptive self-regulatory strategies, and declining self-efficacy (e.g., Blackwell et al., 2007; Dweck \& Leggett, 1988; Schommer, 1990), which themselves have been linked to decreased academic achievement, low persistence, and defeat in the face of difficulty (Bandura, 1986, 1997; Dweck, 1999; Elliot, 1997; Zimmerman \& Martinez-Pons, 1986, 1988).

There is a clear need for science educators to focus their attention on the formative years of students' academic careers to keep them in the science and technology pipeline. Findings from the present study shed light on how students' beliefs both about their ability to learn science and about the nature of scientific knowledge influence their science motivation and achievement, both of which can subsequently influence their decisions to enroll in advanced science classes, participate in science-related college majors, and ultimately to pursue science-related careers.

\section{Research Questions}

The following two research questions guided the present study:

1. What are the associations of implicit theories of ability and epistemological beliefs and their effects on the academic motivation and achievement of Grade 6 science students? The 
motivation constructs include science self-efficacy, self-efficacy for self-regulation, and achievement goal orientations. We hypothesized that incremental views of science ability would be directly positively related to epistemological beliefs about the development and justification of scientific knowledge as well as to task goal orientations and science and selfregulatory self-efficacy. We also hypothesized that fixed views of science ability would be directly positively related to epistemological beliefs about the source and certainty of scientific knowledge as well as to performance goal orientations and directly negatively related to science and self-regulatory self-efficacy.

2. How do implicit theories of science ability, epistemological beliefs about the nature of science, and other variables noted differ as a function of gender and race/ethnicity? We hypothesized that boys would report more incremental views of science ability than would girls and that there would be no gender differences as regards epistemological beliefs. We did not advance any directional hypotheses with regard to race/ethnicity differences in epistemological beliefs.

\section{Methodology}

Participants were 508 Grade 6 science students attending a large, suburban, public middle school in the Southeast. The middle school enrolls over 1,850 students and begins in Grade 6 and ends with Grade 8 . Therefore, this was the first year outside of elementary school for the participants in my study. In the county where this particular school was located, all Grade 6 students in the public school system study Earth Science, which introduces students to topics such as astronomy, meteorology, and geology. Grade 6 represents an important period of time for these adolescents since this is the first time these students have experienced a science curriculum that is taught every day. That is, in elementary school, science was taught only once 
every week. All of the Grade 6 students in the school were asked to participate and about 5\% requested not to participate. There were 97 Asian students (19.1\%), 242 White students (47.6\%), 83 Black students (16.3\%); 51 Hispanic students (10.0\%); and 211 Female students (41.5\%). About $28 \%$ of the students qualified for free or reduced price lunch. In addition, about $3 \%$ of the students are enrolled in the school's English as a Second Language (ESOL) program. A 73-item self-report survey was group administered by the first author and five trained research assistants during the Fall semester of the academic year to students while they were in their science classes. The first author and research assistants provided explicit instructions on how to read and interpret the 6-point Likert scales. Students then answered each question at their own pace, and completed the survey within 30 minutes. Students were encouraged to ask questions if they did not understand a question, at which point the first author or research assistant provided clarification. Achievement data (end-of-term course grades) were collected from school records. Variables in the Study

All motivation variables in the present study were assessed using a 6-point Likert scale. For science self-efficacy, a rating of (1) represented a response of "not at all confident" and a rating of (6) represented a response of "completely confident.” For self-efficacy for selfregulation, a rating of (1) represented a response of "Not well at all" and a rating of (6) represented a response of "Very well." For all other variables, a rating of (1) represented a response of "complete disagreement" and a (6) represented a response of "complete agreement." Scores for each variable were calculated by obtaining a mean value. For academic achievement, midterm (previous achievement) and end-of-term (achievement) grades were collected in numerical form as the teachers marked them in their grade books. Grades ranged from 0-100. Finally, race/ethnicity and gender were self-reported. 


\section{Implicit Theories of Ability}

Items for the Implicit Theories of Science Ability scale were adapted from those used by Dweck (1999), and consisted of six items that asked students specifically about their abilities in science rather than just their general intellectual abilities, as is the case with the original survey. Although Dweck's original scale refers to abilities in general, Stipek and Gralinski (1996) posited that adolescent students may have subject-specific ability beliefs. Therefore, items were worded so as to focus students on the subject of school science. The "self" form for children 10 years and older (Dweck, 1999) was used and worded to ensure that students focused on their ideas about their own science ability rather than on their ideas about people in general. Three items assessed students' entity theory of science ability (e.g., "You have a certain amount of science ability, and you really can't do much to change it" and "Your science ability is something about you that you can't change very much") and three others assessed their incremental theory (e.g., "No matter who you are, you can change your science abilities a lot" and "No matter how much science ability you have, you can always change it quite a bit"). When implicit theories of ability have previously been assessed, alpha coefficients have ranged from .77 to .98 (e.g., Blackwell et al., 2007; Dweck, Chiu, \& Hong, 1995; Hong et al., 1999; Robins \& Pals, 2002). We obtained an alpha coefficient of .69 for fixed entity beliefs and .79 for incremental beliefs.

\section{Epistemological Beliefs}

Epistemological beliefs were assessed along the four core dimensions of the construct with a 26-item instrument adapted from previous work with elementary science students (Elder, 2002). All questions were worded so that students focused specifically on the domain of science. The four core dimensions assessed were as follows: Source ( 5 items) was concerned with beliefs 
about knowledge residing in external authorities (e.g., "Whatever the teacher says in science class is true" and "Everybody has to believe what scientists say"). Certainty (6 items) represented the belief that questions in science have one correct answer (e.g., "All questions in science have one right answer" and "Scientific knowledge is always true"). Note that the source and certainty dimensions were stated from a naïve perspective. Development (6 items) was concerned with beliefs about science as an evolving and constantly changing body of knowledge (e.g., "Sometimes scientists change their minds about what is true in science" and "The ideas in science books sometimes change"). Justification (9 items) was concerned with how students justify scientific claims, specifically as it relates to the role of scientific experiments (e.g., "Good answers are based on evidence from many different experiments" and "A good way to know if something is true is to do an experiment"). Note that the development and justification dimensions were stated from a sophisticated perspective. Conley, Pintrich, Vekiri, and Harrison (2004) used this adapted scale in a study of Grade 5 students attending five elementary schools in the Southwest and reported the following coefficient alphas for the four dimensions, each one measured at two time points: Source (alphas were $.81(\mathrm{t} 1)$ and $.82(\mathrm{t} 2))$; Certainty (alphas $=.78$ and .79); Development (alphas were .57 and .66); and Justification (alphas were .65 and .76). In a recent study, Mason, Gava, and Boldrin (2008) used the Certainty and Development sections of the questionnaire and obtained an overall reliability of $\alpha=.73$. In her original scale, Elder obtained coefficient alphas for the following three dimensions: Development (.67); Justification (.52); and Source (.64). A low coefficient alpha was obtained in Elder's original scale for the "Certainty" dimension $(\alpha<.40)$. In the present study, we administered the Conley et al. adapted scale. Alphas in the present study were as follows: Development (.76); Justification (.83); Source (.67); and Certainty (.74). 


\section{Science Grade Self-efficacy}

Students' confidence in obtaining either an A, B, C, or D in their science class was assessed using a 4-item instrument (e.g., "How confident are you that you will get a grade of "C" or better in science this semester?”) (see Bandura, 1997, for assessment procedures consistent with tenets of self-efficacy theory). Students provided a rating for each of the four grades mentioned above. When researchers have used this scale in the past they have obtained coefficient alphas ranging from .85 to .91 (e.g., Britner \& Pajares, 2001, 2006, in press; Pajares, Britner, \& Valiante, 2000; Usher \& Pajares, 2008). We obtained an alpha coefficient of .83. Researchers in the past have also successfully employed this scale with middle grades students, yielding similar alpha coefficients (Britner \& Pajares, 2006; Pajares, Britner, \& Valiante, 2000; Usher \& Pajares, 2008).

\section{Science Achievement Goal Orientations}

Science achievement goal orientations were assessed using a scale derived from the Patterns of Adaptive Learning Survey (PALS) (Middleton \& Midgley, 1997; Midgley et al., 2000) and adapted to reflect goals toward success in science class. Task goal orientations (5 items) reflect striving to develop one's skills and abilities or advance one's learning and understanding of the material (e.g., "I like science assignments I can learn from, even if I make a lot of mistakes" and "I like science assignments that really make me think"). Performance approach goal orientations (5 items) entail focusing on attaining normative competence (e.g., "I want to do better than other students in my science class" and "I would feel successful at science if I did better than most of the other students in the class"). Performance avoid goal orientations (6 items) entail focusing on avoiding normative competence (e.g., "It's important to me that I don't look stupid in science class" and "An important reason I do my science assignments is so I 
won't embarrass myself'). The following coefficient alphas have been reported for the following goal orientation subscales: Task (alphas ranged from .83 to .89); Performance Approach (alphas ranged from .77 to .80); and Performance Avoid (alphas ranged from .78 to .83) (e.g., Britner \& Pajares, 2001; Middleton \& Midgley, 1997; Pajares, Britner, \& Valiante, 2000; Pajares \& Cheong, 2003; Pajares \& Valiante, 2001). We obtained the following alpha coefficients: Task (.83); Performance Approach (.82); and Performance Avoid (.79).

\section{Self-Efficacy for Self-Regulation}

Self-efficacy for self-regulation in science was assessed using a 7-item subscale adapted from Bandura's Children's Multidimensional Self-Efficacy Scale that assesses students' judgments of their capability to use various self-regulated learning strategies (e.g., "How well can you study when there are other interesting things to do?" and "How well can you finish your homework on time?”) (Zimmerman \& Bandura, 1994). A validation study by Zimmerman and Martinez-Pons (1988) revealed that a single factor underlay the items. Researchers have reported coefficient alphas ranging from .78 to .87 (e.g., Britner \& Pajares, 2001, 2006; Pajares, Miller, \& Johnson, 1999; Usher \& Pajares, 2006; Zimmerman, Bandura, \& Martinez-Pons, 1992). We obtained an alpha coefficient of .82.

\section{Results}

Means, standard deviations, and zero-order correlations for all variables are presented in Table 2. Recall that the first objective of the study was to examine the associations of implicit theories of ability and epistemological beliefs and their effects on the academic motivation and achievement of Grade 6 science students. As predicted by Hofer and Pintrich (1997), incremental theory of ability correlated positively with the development (.30) and justification (.40) of scientific knowledge, both of which are considered "sophisticated" views of the nature of 
scientific knowledge, suggesting that an incremental view of ability is correlated with more sophisticated beliefs about the nature of scientific knowledge and knowing. Holding a fixed view of ability correlated positively with the source (.26) and certainty (.39) of scientific knowledge, both of which are considered "naïve" views about the nature of scientific knowledge, suggesting that holding the belief that science ability is a static trait is correlated with more naïve views about the nature of scientific knowledge.

Holding an incremental theory of ability was also positively correlated with holding a task goal orientation to learning science (.46), and negatively correlated with holding a performance avoid goal orientation (-.18). Believing that science ability is fixed was negatively correlated with task goal orientations (-.30), and positively correlated to performance avoid goal orientations to learning science (.41). These results suggest that holding the view that science ability can be improved is correlated with performing a task for the sake of learning and mastering the material, whereas holding the view that science ability is a fixed quantity is correlated with performance avoid goal orientations, but not with performance approach goal orientations.

\section{Results of the Path Analysis}

The second objective, which formed the substantive core of the study, was to discover the direct and indirect effects of implicit theories and epistemological beliefs on the science motivation and achievement of middle school students. To accomplish this, we analyzed the data using path analytic techniques. The hypothesized model is presented in Figure 1. The hypothesized paths were drawn from previous empirical work and theoretical arguments that suggested the causal ordering of the variables. Recall that, according to Dweck and her colleagues, holding an incremental theory of ability creates a meaning system that leads to a 
series of adaptive motivational beliefs and a more sophisticated worldview, whereas holding an entity theory of ability creates a meaning system that leads to a series of maladaptive beliefs and a less sophisticated worldview (Dweck, Chiu, \& Hong, 1995; Dweck \& Leggett, 1988). Implicit theories, they argued, serve as core assumptions that foster a framework for viewing a particular domain. Moreover, Hofer and Pintrich (1997) suggested that beliefs about intellectual ability may serve as precursors to epistemological beliefs. Empirical evidence also suggests that naïve epistemological beliefs tend to be related to task goal orientations (Bråten \& Strøms $\varnothing, 2004$, 2006). Goal orientations, as suggested by empirical evidence, are thought to be directly related to academic and self-regulatory self-efficacy (Middleton \& Midgley, 1997; Pajares, Britner, \& Valiante, 2000; Pajares, Miller, \& Johnson, 1999). Finally, no direct paths were drawn between goal orientations and academic achievement, based on past empirical evidence suggesting that goal orientations' influence on achievement is mediated by other motivational variables (Blackwell et al., 2007; Dupeyrate \& Mariné, 2005). Figure 2 illustrates the final path analysis model with nonsignificant paths removed. The results of the path analysis indicate that the model explained the data well-fit indices provided evidence of adequate model-to-data fit: $\chi^{2}(38, \mathrm{~N}=$ $508)=121.75, p<.0001 ;$ Root Mean Square Error of Approximation $($ RMSEA $)=.07$; Nonnormed Index $(\mathrm{NNFI})=.93$; and Comparative Fit Index $(\mathrm{CFI})=.96$. Moreover, several different models were tested, but the model in Figure 2 was chosen because it was the most parsimonious. One final note should be made about the model. To discover whether the relationships would vary by race/ethnicity or gender, another analysis was conducted controlling for the effects of race/ethnicity and gender. Paths were not significantly changed, and for this reason we omitted gender and ethnicity from the model for the sake of simplicity of interpretation. Table 3 provides a decomposition of effects from the path analysis. The independent variables accounted for $38 \%$ 
of the variability in science achievement. In previous studies investigating epistemological beliefs, academic motivation, and/or academic achievement, similar results have been found (e.g., Ozkal, Tekkaya, Cakiroglu, \& Sungur, 2009; Schommer-Aikins, Duell, \& Hutter, 2005). For example, Kizilgunes, Tekkaya, and Sungur (2009) found that the four dimensions of epistemological beliefs, goal orientations, and self-efficacy accounted for $38 \%$ of the variance in what they called "learning approaches," defined as students' tendency toward meaningful or rote learning, which itself was directly related to academic achievement.

As hypothesized by Hofer and Pintrich (1997) and was foreshadowed by correlational results, holding the view that science ability can be increased had direct effects on sophisticated epistemological beliefs, which include the belief that scientific knowledge is contextual and consists of interrelated concepts (Development) $(\beta=.297, t=7.39, p<.0001)$ and the belief that experiments are used to test hypotheses and generate knowledge (Justification) $(\beta=.356$, $t=8.76, p<.0001$ ); holding the view that science ability is fixed had direct effects on naïve epistemological beliefs, which include the belief that knowledge originates within external authorities (Source) $(\beta=.213, t=5.03, p<.0001)$ and the belief that knowledge does not evolve (Certainty) $(\beta=.305, t=7.59, p<.0001)$. Consistent with previous empirical results, epistemological beliefs about the development $(\gamma=.111, t=2.86, p<.01)$ and certainty $(\gamma=-.212, t=-5.44, p<.0001)$ of scientific knowledge had direct effects on science achievement, suggesting that holding the view that scientific knowledge can change based on new evidence is directly positively related to achievement, whereas holding the view that knowledge remains static is directly negatively related to achievement. The sophisticated view that experiments are not merely classroom activities, but rather are tools used to test ideas (Justification), was directly positively related to task goal orientations $(\gamma=.368, t=9.39$, 
$p<.0001)$ and was directly positively related to academic self-efficacy $(\gamma=.143, t=3.78$, $p<.001)$. Holding the view that absolute scientific truth exists (Certainty) was positively related to performance-avoid goal orientations $(\beta=.272, t=6.69, p<.0001)$ and negatively related to self-efficacy $(\beta=-.194, t=-5.33, p<.0001)$. Taken together, these results suggest that espousing naïve views about the nature of scientific knowledge is related to maladaptive motivational beliefs and lower academic achievement. Espousing sophisticated views about the nature of science is related to adaptive motivational beliefs and higher academic achievement.

Table 4 provides an overview of the direct and indirect effects on science achievement of each of the variables in the study. Two effects are noteworthy. Holding the view that science ability can be improved with effort, though not directly related to science achievement, had an indirect effect $(\beta=.130)$ on science achievement, largely through epistemological beliefs about the development and the justification of knowledge, task goal orientations, and self-efficacy for self-regulation. The second effect worth noting is that holding the view that science ability is fixed had a negative indirect effect $(\beta=-.104)$ on science achievement, largely mediated through epistemological beliefs about the source and certainty of scientific knowledge and performance avoid goal orientations.

\section{Gender and Race/Ethnicity Differences}

The final objective of the study was to detect differences in students' implicit theories of ability, epistemological beliefs, and other motivational variables as a function of gender or race/ethnicity. Table 5 provides means and standard deviations for all variables by gender and race/ethnicity. As regards gender, boys and girls differed in only one of the variables assessed. Boys reported stronger views about the incremental nature of science ability than did girls $(\mathrm{M}=$ 4.8 to 4.5$)$. As regards race/ethnicity, significant differences were detected for only two of the 
variables in the study_epistemological beliefs about the source and certainty of scientific knowledge. When controlling for previous achievement, both Asian $(\mathrm{M}=3.3)$ and Hispanic (M $=3.3$ ) students reported higher scores on epistemological beliefs about the source of scientific knowledge than did either the White or Black students. Recall that higher scores on this particular scale represent the more naïve view that scientific knowledge is handed down from authorities. Also, when controlling for previous achievement, Hispanic students $(\mathrm{M}=3.4)$ reported higher scores on epistemological beliefs about the certainty of scientific knowledge than did students from any other racial/ethnic background. Asian $(M=2.9)$ and Black $(M=2.9)$ students reported higher scores on this particular scale than did White students $(\mathrm{M}=2.6)$. Recall that higher scores on the scale assessing epistemological beliefs about the certainty of scientific knowledge correspond with the belief in a constant absolute truth in science (the more naïve view). We found no interaction between gender and race.

\section{Discussion}

Dweck and Leggett (1988) observed that philosophers, psychologists, and linguists have for many years been describing the consequences of presupposing the world as one of static objects versus dynamic, evolving processes. Those who view attributes as static, they argued, are more likely to "display a tendency to derive oversimplified, all-or-nothing characterizations from a small sample of actions or outcomes" (p. 267). It follows, then, that those who adhere to a fixed view of science ability are more likely to develop oversimplified, or naïve, views of science knowledge.

The main findings of the present study support this view-holding the view that science ability can be improved was directly related to sophisticated beliefs about the nature of scientific knowledge, whereas holding the view that science ability is a fixed trait was directly related to 
naïve views about the nature of scientific knowledge. More sophisticated epistemological beliefs in turn are directly related to science achievement, self-efficacy, and task goal orientations, whereas naïve views about the nature of scientific knowledge are directly related to performance goal orientations, anxiety, and decreased science achievement and self-efficacy. These results provide support for Hofer and Pintrich's (1997) hypothesis that beliefs about learning and ability may be precursors to beliefs about knowledge and knowing. Hofer and Pintrich posited that beliefs about the nature of knowledge and knowing may be relatively late-developing, but beliefs about learning, teaching, or ability begin to develop relatively early. Indeed, Dweck (1999) argued that important conceptions about the self are alive and well in young children. She argued that preschool children have elaborate beliefs about goodness and badness and how static or malleable these traits are. Though little to no empirical evidence exists to date, Dweck posited that,

children must be constructing a system of beliefs about themselves and their social world pretty much from the start. The greatest challenge in social development is to figure out what these beliefs are, what role they play in adaptive functioning, and how they may change with later experiences. (pp. 143-144)

Beliefs about the nature of knowledge and knowing and conceptions of ability are likely closely related. As we will discuss next, these beliefs might even be borne of a similar worldview. The findings of the present study also bolster Dweck's (2002) contention that implicit theories of ability become linked together to form a network with other beliefs, values, and goals, which in turn have consequences for students' motivation and achievement. It is possible that, along with achievement goal orientations, attributions, and beliefs about effort, epistemological 
beliefs could also be linked to this "meaning system.” Dweck, Chiu, and Hong (1995) observed that

Alfred North Whitehead distinguished between a static world view and a dynamic world view. These two distinct views of reality differ in terms of (a) their core ontological assumption about the nature of reality (whether it is static or evolving), and (b) their epistemological approach to knowing this reality (whether the reality is best known by quantifying and measuring its unchangeable dispositions or by analyzing its dynamic processes). (p. 282)

The dimensions of epistemological beliefs include aspects of this idea of a static versus dynamic nature of scientific knowledge. For example, the "Certainty of Scientific Knowledge" dimension is described as the degree to which one sees scientific knowledge as stable or fluid. At more naïve ends of the spectrum, students believe that absolute truth exists with certainty and that scientific knowledge is a collection of right or wrong answers. At more sophisticated levels, students believe that scientific knowledge is tentative and constantly evolving. Clearly, there is a link between the dimensions of epistemological beliefs and implicit theories of ability. For this reason, Hofer and Pintrich (1997) hypothesized that epistemological beliefs may function as implicit theories that give rise to certain achievement goal orientations. Though no claim can be made that the relationship between implicit theories and epistemological beliefs is causal, what Dweck, Chiu, and Hong suggest is that beliefs about the nature of scientific knowledge and beliefs about the malleability of science ability may result from a larger worldview-a view about whether characteristics of the self and characteristics of the world around them are generally static or dynamic. 
It is important to note that the relationships described in the present study between implicit theories of ability, epistemological beliefs, achievement goal orientations, and academic motivation and achievement arose among Grade 6 students. Dweck (2002) posited that beliefs about ability begin to crystallize and become linked with a host of other beliefs and motivational constructs from 10-12 years of age. Before this age, students may possess beliefs about ability, but these beliefs are not as likely to influence other motivational constructs. But is the linking of implicit theories of ability to other beliefs, goals, and values a matter of cognitive development or the belief in a world of dynamic, complex qualities? Dweck argued that although younger children may endorse a view of intelligence as a fixed trait, such a view does not seem to predict impairment in the face of failure until about 10-12 years of age. Thus, some fuller understanding of what "ability as a fixed trait" means must be achieved. However, it cannot be all a matter of cognitive advancement, for this would mean that at some age, everyone would start being noticeably impaired after failure, and this is not the case. It would appear, then, that for older students, impairment in the face of failure might require both an understanding of ability or intelligence as a potentially stable trait and the adoption of the view of ability as unmalleable. (Dweck, 2002, p. 70)

Dweck argues that the formation of this network of beliefs, with implicit theories at the heart of it all, hinges on whether people believe that their abilities are fixed or not. Her argument suggests that the beliefs adolescents hold can have a remarkable effect on their academic achievement and motivation, regardless of factors such as previous achievement or developmental level. However, it is possible, especially given the age of the participants in the present study, that there are also developmental issues that affect the nature and strength of relationships between the variables. If, 
as Dweck argued, implicit theories do not tend to have a motivational (or demotivational) impact until about 10-12 years of age, then the students in the present study, who range in age from 11 to 13 years of age, may only be starting to form their conceptions of science ability and about the nature of science. Future research will need to examine this developmental issue, perhaps by studying the relationships between implicit theories of ability, epistemological beliefs, and academic motivation and achievement among older students to discover whether the relationships between these constructs vary as a function of age, educational attainment, and cognitive development.

\section{Gender and Race/Ethnicity}

Another objective of the present study was to examine differences in students' implicit theories of ability, epistemological beliefs, and other motivational variables as a function of gender or race/ethnicity. As regards gender, we found that while both girls and boys reported, on average, more incremental beliefs about ability, the boys reported slightly higher incremental views of ability than did the girls, though the differences between the means was relatively small. These results were foreshadowed by Dweck (1999), who contended that girls, especially high-achieving girls, may more often than boys operate in the trait-focused system. They have been shown in some studies to hold more of an entity theory of intelligence and to attribute failures more to lack of ability. Along with this, they have also been widely shown to have lower estimates of their ability and lower expectations of success in many areas. (p. 78) 
In a theoretical piece, Dweck (2006) hypothesized that girls' lower estimations of ability may result from the messages they receive from parents and teachers that girls are less competent in science and math.

As hypothesized by Pintrich (2002), there were no gender differences with regard to epistemological beliefs. Pintrich suggested that when epistemological beliefs are defined in terms of separate dimensions and students are asked to focus on specific dimensions, rather than thinking of epistemological beliefs more holistically, there will be no gender differences in epistemological beliefs.

As regards race/ethnicity, results of the study suggest that, when controlling for previous achievement, Hispanic students ascribe to more naïve beliefs about the certainty of scientific knowledge compared to their Asian, White, and African American peers. Hispanic students and Asian students ascribed to more naïve beliefs about the source of scientific knowledge, compared to their African American and White peers. Although differences in implicit theories of ability and epistemological beliefs about the development or the justification of knowledge were not statistically significant, Hispanic students did score consistently lower compared to their peers. Two cautions should be noted, however. First, calling certain beliefs naïve, such as the belief that the source of scientific knowledge comes only from those in authority, is a product of Western thought (Hofer, 2006). Different cultures have different standards about what is considered naïve or sophisticated beliefs about knowledge and knowing. For example, individuals from Asian cultures generally deem it appropriate to show deference to one's elders and therefore place much trust in information from those in authority (Chan \& Elliott, 2002). To deem the cultural value of trusting information from those in authority as less sophisticated is, as Hofer (2006) admonished, "pejorative" and that "greater cultural explorations may help us move away from 
the hegemony of western ideas of 'sophistication' and toward a view of epistemic understanding that is more contextual and culturally situated" (p. 16). Our conceptions of sophisticated and naïve perspectives of knowledge and knowing therefore need to be carefully considered.

The second caution to be noted is that naïve beliefs are not always maladaptive and sophisticated beliefs are not always adaptive. Much research has accumulated suggesting that naïve beliefs are generally related to poorer academic performance and more sophisticated beliefs are generally related to better academic performance (Buehl \& Alexander, 2005; Kardash \& Howell, 2000; Schommer et al., 1992; Schommer \& Walker, 1995). However, while this may be true for some dimensions of epistemological beliefs within certain learning contexts, it may not be the case with other dimensions or within other learning contexts. For example, Bråten, Strøms $\varnothing$, and Samuelstuen (2008) noted that with regard to text comprehension, ascribing to the belief that knowledge about climate change is primarily constructed by the individual (a more sophisticated belief about the source of knowledge) was related to poorer performance on a text comprehension test, controlling for prior knowledge, gender, and age. Thus, discovering whether or not certain epistemological beliefs are adaptive should be carefully considered within the context of the activity students are performing and the academic discipline under which they are operating.

\section{Limitations}

Finally, it bears noting some of the limitations of the present study. First, we used selfreport surveys to assess students' beliefs at one time point. Though much work has been done investigating how epistemological beliefs evolve over time, less has been done discovering how the relationships to other motivational variables change as students progress through their educational careers. Hofer and Pintrich (1997) have suggested that epistemological beliefs may 
be recursive — as students make difficult transitions, such as from elementary school to middle school, they may regress back to more naïve beliefs about knowledge and knowing. Then, as they progress through middle school their beliefs may become more sophisticated, only to regress again when they are met with another difficult transition, say from middle school to high school. If this is the case, how do the relationships between epistemological beliefs, implicit theories, and academic motivation and achievement change over the course of this recursive developmental trajectory? Longitudinal data investigating changes in the relationships between these important beliefs over time, especially at difficult transitions, are therefore warranted. Epistemological beliefs are also domain-specific. Therefore, investigating changes in the relationships between these beliefs over time in various subject areas may also prove fruitful.

\section{Implications}

These findings have implications for science teachers. Explicitly teaching students that their science abilities can be improved with effort may help students to better appreciate the value of processes such as learning to solve new problems and dealing with failures by planning alternative strategies, rather than placing undue emphasis on products such as test scores and report card grades. Bandura (1997) noted that

people often forsake realizable challenges because they believe they require extraordinary aptitude ... People see the extraordinary feats of others but not the unwavering commitment and countless hours of perseverant effort that produced them. Such partial information generally leads people to overestimate inherited endowments and underestimate self-regulatory factors in human accomplishments. (p. 119) 
This emphasis on extraordinary aptitude or innate qualities permeates much of what young people observe on television, from their friends and family, and in their math and science classrooms (Dweck, 2006). For example, students often hear messages about the scientific genius of scientists like Kekule, who discovered the ring-like structure of organic compounds while reportedly having an inspirational dream, or that Albert Einstein's genius can be explained by looking at his brain — he had a brain with an unusually large area dedicated to mathematical and spatial reasoning. Students rarely hear stories about the endless numbers of failures and the years of intense labor required to produce influential work. Teachers and parents would do well to confront these messages directly and emphasize the value of great accomplishment through hard work and persevering through failures.

Teachers can explicitly teach their students about the malleability of science ability. For example, Blackwell et al. (2007) designed an intervention in which middle school students were explicitly taught a series of lessons about the malleability of intelligence using and extending models of theory-altering interventions developed by other researchers (Aronson, Fried, \& Good, 2002; Chiu, Hong, \& Dweck, 1997). During the course of these interventions college students were taught that intellectual abilities are malleable and were then assigned to pen pals who were "at risk" middle school students. The college students wrote letters to their pen pals convincing them that with effort, intellectual abilities could be improved. When compared to a control group, these interventions were effective in changing students' implicit theories of ability and the trajectory of their academic achievement. Such an approach may well be incorporated into the conversations and lessons in which teachers, parents, and students engage.

For science teachers in particular, it is also critical to explicitly teach students that scientific knowledge is complex, constantly evolving, and is empirically developed (Lederman, 
1999). What can teachers do to develop their students' beliefs about scientific knowledge and knowing? Suggestions about what instructional techniques to employ are relatively sparse, mostly because researchers have little empirical evidence about how students acquire beliefs and how they change their beliefs (Hofer, 2001). Any suggestions that deal with epistemological beliefs tend to be broad recommendations such as teaching students that the model of the atom, for example, has changed numerous times and why such changes were deemed necessary. An historical approach, however, does not explicitly teach students about the nature of scientific knowledge and knowing. Its value, therefore, has been called into question.

In contrast, empirical support has accumulated suggesting that debate style argumentation and collaborative debate in the science curriculum can have a positive effect on improving students' conceptions of scientific knowledge. Bricker and Bell (2008) stated that "argumentation is critical to producing, evaluating, and therefore, advancing scientific knowledge" and for this reason "should be a core component of school science — as a way to help students engage with the social construction of scientific ideas as well as learn about the workings of the scientific enterprise" (p. 474). Collaborative debate, where students work in teams to understand and resolve a problem, can be particularly effective in improving students' understanding about the nature of scientific knowledge and knowing. Scientists engage in this type of activity continuously, and such activities can help promote conceptual change because in the process of talking and debating students must make their ideas and conceptions known, which may afford avenues for cognitive dissonance (Bricker \& Bell, 2008).

Argumentation may also help students connect what they learn in science class to what they know in their own personal lives outside of the classroom (Bell \& Linn, 2002). By connecting school science to students' lives, science becomes relevant, and as Alfred North 
Whitehead (1929/1967) argued nearly a century ago in his treatise The Aims of Education, “theoretical ideas should always find important applications within the pupil's curriculum ... [this doctrine] contains within itself the problem of keeping knowledge alive, of preventing it from becoming inert, which is the central problem of all education” (p. 5). Inert ideas, as Whitehead argued, are not only useless, they are "above all things, harmful—Corruptio optima, pessima." By seeing connections between science, current events, mathematics, and even the daily lives of ordinary people, students can view science as dynamic, highly interconnected, even controversial. When students develop their conceptions of scientific knowledge and come to learn that their ability to do science is a malleable quality, they place themselves in a better position to become lifelong science learners. 


\section{References}

Aronson, J., Fried, C. B., \& Good, C. (2002). Reducing the effects of stereotype threat on African American college students by shaping theories of intelligence. Journal of Experimental Social Psychology, 38, 113-125.

American Association for the Advancement of Science. (1993). Benchmarks for scientific literacy. New York: Oxford University Press.

Anderman, E. M., \& Maehr, M. L. (1994). Motivation and schooling in the middle grades. Review of educational Research, 64, 287-310.

Bandura, A. (1997). Self-efficacy: The exercise of control. New York: W.H. Freeman.

Bell, P. \& Linn, M. C. (2002). Beliefs about science: How does science instruction contribute? In B. K. Hofer \& P. R. Pintrich (Eds.), Personal Epistemology: The psychology of beliefs about knowledge and knowing (pp. 321-346). Mahwah, NJ: Erlbaum.

Blackwell, L. S., Trzesniewski, K. H., \& Dweck, C. S. (2007). Implicit theories of intelligence predict achievement across an adolescent transition: A longitudinal study and an intervention. Child Development, 78, 246-263.

Bråten, I., \& Olaussen, B. S. (1998). The relationship between motivational beliefs and learning strategy use among Norwegian college students. Contemporary Educational Psychology, 23, 182-194.

Bråten, I., \& Olaussen, B. S. (2005). Profiling individual differences in student motivation: A longitudinal cluster-analytic study in different academic contexts. Contemporary Educational Psychology, 30, 359-396.

Bråten, I., \& Strømsø, H. I. (2004). Epistemological beliefs and implicit theories of intelligence as predictors of achievement goals. Contemporary Educational Psychology, 29, 371-388. 
Bråten, I., \& Strøms $\varnothing$, H. I., \& Samuelstuen, M. S. (2008). Are sophisticated students always better? The role of topic-specific personal epistemology in the understanding of multiple expository texts. Contemporary Educational Psychology, 33, 814-840.

Bricker, L. A. \& Bell, P. (2008). Conceptualizations of argumentation from science studies and the learning sciences and their implications for the practices of science education. Science Education, 92, 473-498.

Britner, S. L., \& Pajares, F. (2001). Self-efficacy beliefs, race, and gender in middle school science. Journal of Women and Minorities in Science and Engineering, 7, 271-285.

Britner, S. L., \& Pajares, F. (2006). Sources of science self-efficacy beliefs of middle school students. Journal for Research in Science Teaching, 43, 485-499.

Britner, S. L., \& Pajares, F. (in press). Science anxiety, self-efficacy, and self-concept of undergraduate biology students. In F. Columbus (Ed.), Teacher Education: Policy, Practice, and Research. New York: Nova Science Publishers.

Buehl, M. M., \& Alexander, P. A. (2005). Motivation and performance differences in students' domain-specific epistemological belief profiles. American Educational Research Journal, 42, 697-726.

Chan, K. W., \& Elliott, R. G. (2002). Exploratory study of Hong Kong teacher education students' epistemological beliefs: Cultural perspectives and implications on beliefs research. Contemporary Educational Psychology, 27, 392-414.

Chiu, C., Hong, Y., \& Dweck, C. S. (1997). Lay dispositionism and implicit theories of personality. Journal of Personality and Social Psychology, 73, 923-940. 
Conley, A. M., Pintrich, P. R., Vekiri, I., \& Harrison, D. (2004). Changes in epistemological beliefs in elementary science students. Contemporary Educational Psychology, 29, 186204.

Dupeyrat, C., \& Mariné, C. (2005). Implicit theories of intelligence, goal orientation, cognitive engagement, and achievement: A test of Dweck's model with returning to school adults. Contemporary Educational Psychology, 30, 43-59.

Dweck, C. S. (Ed.). (1999). Self-theories: Their role in motivation, personality, and development. Philadelphia: Psychology Press.

Dweck, C. S. (2002). The development of ability conceptions. In A. Wigfield \& J. S. Eccles (Eds.), The development of achievement motivation. San Diego: Academic Press.

Dweck, C. S. (2006). Is math a gift? Beliefs that put females at risk. In S. J. Ceci \& W. M. Williams (Eds.), Why aren't more women in science? Top researchers debate the evidence (pp. 47-55). Washington, DC: American Psychological Association.

Dweck, C. S., Chiu, C. Y., \& Hong, Y. Y. (1995). Implicit theories and their role in judgments and reactions: A world from two perspectives. Psychological Inquiry, 6, 267-285.

Dweck, C. S., \& Leggett, E. L. (1988). A social cognitive approach to motivation and personality. Psychological Review, 95, 256-273.

Dweck, C. S., \& Master, A. (2008). Self-theories motivate self-regulated learning. In D. H. Schunk \& B. J. Zimmerman (Eds.), Motivation and self-regulated learning: Theory, research, and applications (pp. 31-51). New York: Taylor \& Francis.

Eccles, J. S. (2004). Schools, academic motivation, and stage-environment fit. In R. M. Lerner \& L. D. Steinberg (Eds.), Handbook of adolescent psychology (2nd ed., pp. 125-153). New York: Wiley. 
Eccles, J. S., Midgley, C., Wigfield, A., Buchanan, C. M., Reuman, D., Flanagan, C., \& MacIver, D. (1993). Development during adolescence: The impact of stage-environment fit on young adolescents' experiences in schools and in families. American Psychologist, 48, 90-101.

Elder, A. D. (2002). Characterizing fifth grade students' epistemological beliefs in science. In B. K. Hofer \& P. R. Pintrich (Eds.), Personal Epistemology: The psychology of beliefs about knowledge and knowing (pp. 347-364). Mahwah, NJ: Lawrence Erlbaum Associates.

Elliot, A. J., (1997). Integrating the "classic" and "contemporary" approaches to achievement motivation: A hierarchical model of approach and avoidance achievement motivation. In M. L., \& P. R. Pintrich (Eds.), Advances in motivation and achievement (Vol. 10, pp. 143-179). Greenwich, CT: JAI Press.

Hofer, B. K. (2000). Dimensionality and disciplinary differences in personal epistemology. Contemporary Educational Psychology, 25, 378-405.

Hofer, B. K. (2001). Personal epistemology research: Implications for learning and teaching. Journal of Educational Psychology Review, 13, 353-383.

Hofer, B. K. (2006). Personal epistemology and culture. In M. S. Khine (Ed.), Knowing, knowledge, and beliefs: Epistemological studies across diverse cultures (pp. 3-22). Berlin: Springer.

Hofer, B. K., \& Pintrich, P. R. (1997). The development of epistemological theories: Beliefs about knowledge and knowing and their relation to learning. Review of Educational Research, 67, 88-140.

Hofer, B. K., \& Pintrich, P. R. (Eds.). (2002). Personal epistemology: The psychology of beliefs about knowledge and knowing. Mahwah, NJ: Erlbaum. 
Hong, Y. Y., Chiu, C. Y., Dweck, C. S., Lin, D. M. S., \& Wan, W. (1999). Implicit theories, attributions, and coping: A meaning system approach. Journal of Personality and Social Psychology, 77, 588-599.

Kardash, C. M., \& Howell, K. L. (2000). Effects of epistemological beliefs and topic-specific beliefs on undergraduates' cognitive and strategic processing of dual-positional text. Journal of Educational Psychology, 92, 524-535.

Kizilgunes, B., Tekkaya, C., \& Sungur, S. (2009). Modeling the relations among students' epistemological beliefs, motivation, learning approach, and achievement. Journal of Educational Research, 102, 243-255.

Lederman, N. G. (1999). Teachers' understanding of the nature of science and classroom practice: Factors that facilitate or impede the relationship. Journal of Research in Science Teaching, 36, 916-929.

Mason, L., Gava, M., and Boldrin, A. (2008). On warm conceptual change: The interplay of text, epistemological beliefs, and topic interest. Journal of Educational Psychology, 100, 291309.

Middleton, M. J., \& Midgley, C. (1997). Avoiding the demonstration of lack of ability: An underexplored aspect of goal theory. Journal of Educational Psychology, 89, 710-718.

Midgley, C., Maehr, M. L., Hruda, L. Z., Anderman, E., Anderman, L., Freeman, K. E., et al. (2000). Manual for the patterns of adaptive learning scales (PALS). Ann Arbor, MI: University of Michigan.

Molden, D. C., \& Dweck, C. S. (2006). Finding “meaning” in psychology. American Psychologist, 61, 192-203. 
Montemayor, R., Adams, G. R., Gullotta, T. P. (1990). From childhood to adolescence: A transitional period? Thousand Oaks, CA: Sage.

National Research Council. (1996). National science education standards. Washington, DC: National Academic Press.

Ommundsen, Y. (2003). Implicit Theories of Ability and Self-regulation Strategies in Physical Education Classes. Educational Psychology, 23, 141.

Ozkal, K., Tekkaya, C., Cakiroglu, J., \& Sungur, S. (2009). A conceptual model of relationships among constructivist learning environment perceptions, epistemological beliefs, and learning approaches. Learning and Individual Differences, 19, 71-79.

Pajares, F. (1996). Self-efficacy beliefs in academic settings. Review of Educational Research, 66, 543-548.

Pajares, F., Britner, S. L., \& Valiante, G. (2000). Relation between achievement goals and selfbeliefs of middle school students in writing and science. Contemporary Educational Psychology, 25, 406-422.

Pajares, F., \& Cheong, Y. F. (2003). Achievement goal orientations in writing: A developmental perspective. International Journal of Educational Research, 39, 437-455.

Pajares, F., \& Graham, L. (1999). Self-efficacy, motivation constructs, and mathematics performance of entering middle school students. Contemporary Educational Psychology, $24,124-139$.

Pajares, F., \& Kranzler, J. (1995). Self-efficacy beliefs and general mental ability in mathematical problem-solving. Contemporary Educational Psychology, 20, 426-443.

Pajares, F., Miller, M. D., \& Johnson, M. J. (1999). Gender differences in writing self-beliefs of elementary school students. Journal of Educational Psychology, 91, 50-61. 
Pajares, F., \& Valiante, G. (1999). Grade level and gender differences in the writing self-beliefs of middle school students. Contemporary Educational Psychology, 24, 390-405.

Pajares, F., \& Valiante, G. (2001). Gender differences in writing motivation and achievement of middle school students: A function of gender orientation? Contemporary Educational Psychology, 26, 366-381.

Pintrich, P. R. (2002). Future challenges and directions for theory and research on personal epistemology. In B. K. Hofer \& P. R. Pintrich (Eds.), Personal Epistemology: The psychology of beliefs about knowledge and knowing (pp. 389-414). Mahwah, NJ: Erlbaum.

Robins, R. W., \& Pals, J. L. (2002). Implicit Self-Theories in the Academic Domain: Implications for Goal Orientation, Attributions, Affect, and Self-Esteem Change. Self \& Identity, 1, 313-336.

Schommer, M. (1990). Effects of beliefs about the nature of knowledge comprehension. Journal of Educational Psychology, 82, 498-504.

Schommer, M., Crouse, A., \& Rhodes, N. (1992). Epistemological beliefs and mathematical text comprehension: Believing it is simple does not make it so Journal of Educational Psychology, 84, 435-443.

Schommer, M., \& Walker, K. (1995). Are epistemological beliefs similar across domains? Journal of Educational Psychology, 87, 424-432.

Schommer-Aikins, M., Duell, O. K., \& Hutter, R. (2005). Epistemological beliefs, mathematical problem-solving beliefs, and academic performance of middle school students. The Elementary School Journal, 105, 289-304. 
Solomon, J., Duveen, J., Scot, L., \& McCarthy, S. (1992). Teaching about the nature of science through history: Action research in the classroom. Journal of Research in Science Teaching, 29, 409-421.

Stipek, D. (2002). Motivation to learn: Integrating theory and practice (4th ed.). Boston: Allyn and Bacon.

Stipek, D., \& Gralinski, J. H. (1996). Children’s beliefs about intelligence and school performance. Journal of Educational Psychology, 88, 397-407.

Tabernero, C., \& Wood, R. E. (1999). Implicit theories versus the social construal of ability in self-regulation and performance on a complex task. Organizational Behavior and Human Decision Processes, 78, 104-127.

Usher, E. L., \& Pajares, F. (2006). Sources of academic and self-regulatory efficacy beliefs of entering middle school students. Contemporary Educational Psychology, 31, 125-141.

Usher, E. L., \& Pajares, F. (2008). Self-efficacy for self-regulated learning: A validation study. Educational and Psychological Measurement, 68, 443-463.

Whitehead, A. N. (1929/1967). The aims of education and other essays.

Wigfield, A., Byrnes, J. B., \& Eccles, J. S. (2006). Adolescent development. In P. A. Alexander \& P. Winne (Eds.), Handbook of educational psychology (2nd edition, pp. 87-113). Mahwah, NJ: Erlbaum.

Wigfield, A., Eccles, J. S., \& Pintrich, P. (1996). Development between the ages of 11 and 25. In D. Berliner \& R. Calfree (Eds.), Handbook of educational psychology. New York: Macmillan.

Zimmerman, B. J., \& Bandura, A. (1994). Impact of self-regulatory influences on writing course attainment. American Educational Research Journal, 31, 845-862. 
Zimmerman, B. J., Bandura, A., \& Martinez-Pons, M. (1992). Self-motivation for academic attainment: The role of self-efficacy beliefs and personal goal setting. American Educational Research Journal, 29, 663-676.

Zimmerman, B. J., \& Martinez-Pons, M. (1986). Development of a structured interview for assessing student use of learning strategies. American Educational Research Journal, 23, 614-628.

Zimmerman, B. J., \& Martinez-Pons, M. (1988). Construct validation of a strategy model of student self-regulated learning. Journal of Educational Psychology, 80, 284-290. 
Table 1

Implicit Theories, Goal Orientations, Perceived Competence, and Behavior Patterns in Achievement Situations (Dweck \& Leggett, 1988)

\begin{tabular}{|c|c|c|c|}
\hline $\begin{array}{c}\text { Theory of } \\
\text { Intelligence }\end{array}$ & Goal Orientation & $\begin{array}{c}\text { Perceived } \\
\text { Competence }\end{array}$ & Behavior Pattern \\
\hline Entity & Performance & High & Mastery Oriented \\
\cline { 3 - 4 } & Learning & Low & Helpless Oriented \\
\hline Incremental & High or Low & Mastery Oriented \\
\hline
\end{tabular}




\section{Figure}

Click here to download high resolution image

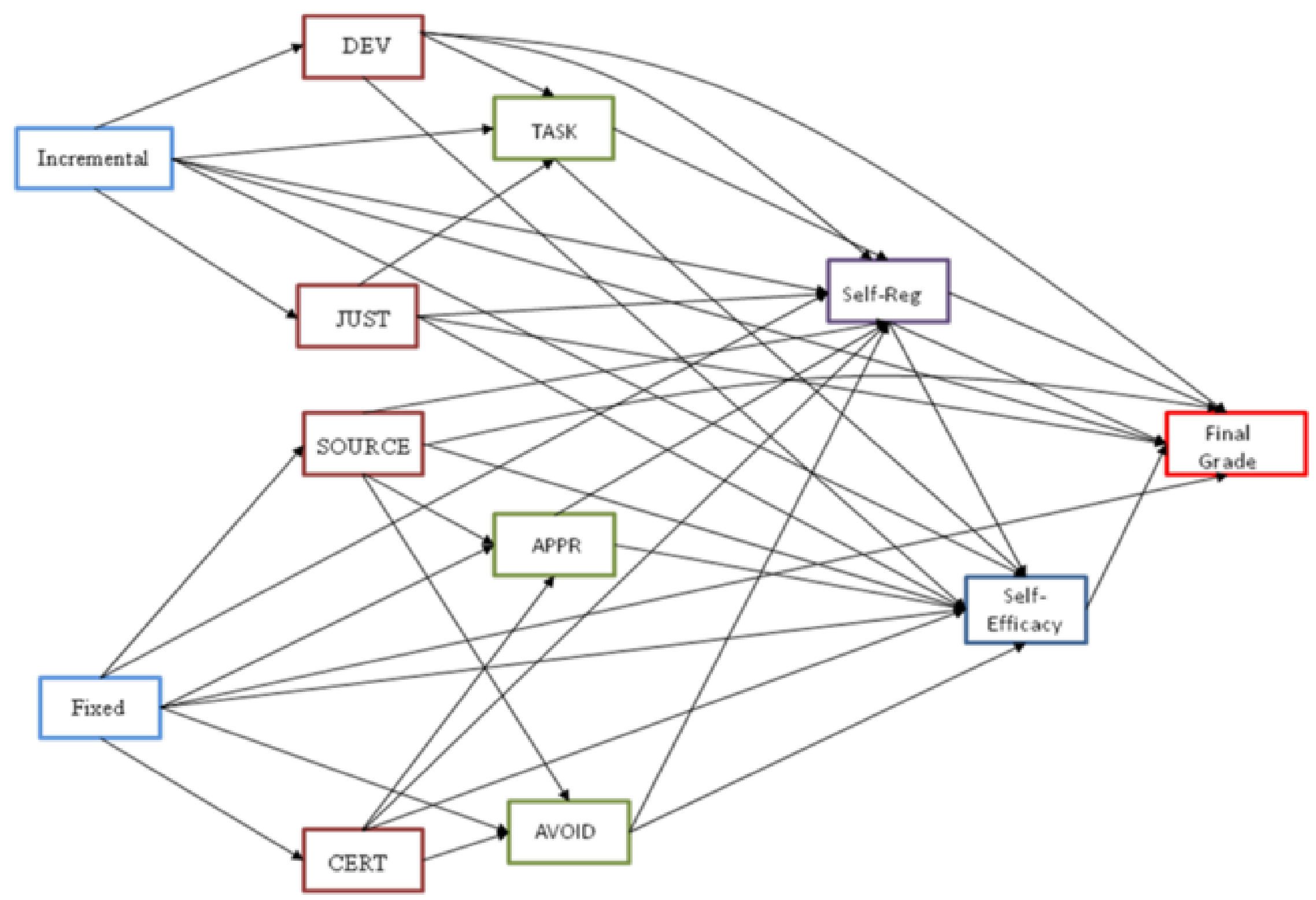

Figure 1. Hypothesized path model representing relationships among variables in the study 
Table 2

Means, Standard Deviations, and Zero-Order Correlations of Variables in the Path Analysis

\begin{tabular}{|c|c|c|c|c|c|c|c|c|c|c|c|c|c|}
\hline Variable & M & SD & Incremental & Fixed & $\begin{array}{c}\text { Epist. } \\
\text { Beliefs } \\
\text { (Source) }\end{array}$ & $\begin{array}{c}\text { Epist. } \\
\text { Beliefs } \\
\text { (Dvlpmt) }\end{array}$ & $\begin{array}{c}\text { Epist. } \\
\text { Beliefs } \\
\text { (Certain) }\end{array}$ & $\begin{array}{l}\text { Epist. } \\
\text { Beliefs } \\
\text { (Justif) }\end{array}$ & $\begin{array}{l}\text { Task } \\
\text { Goal }\end{array}$ & $\begin{array}{l}\text { Perf. } \\
\text { Approach } \\
\text { Goal } \\
\end{array}$ & $\begin{array}{c}\text { Perf. } \\
\text { Avoid } \\
\text { Goal } \\
\end{array}$ & $\begin{array}{c}\text { Self } \\
\text { Efficacy }\end{array}$ & $\begin{array}{l}\text { SE for } \\
\text { Self-Reg }\end{array}$ \\
\hline Incremental & 4.8 & 1.1 & & & & & & & & & & & \\
\hline Fixed & 2.9 & 1.3 & $-.52 * * *$ & & & & & & & & & & \\
\hline Epist. Beliefs (Source) & 3.1 & 1.0 & -.07 & $.26 * * *$ & & & & & & & & & \\
\hline Epist. Beliefs (Dvlpmt) & 5.1 & 0.8 & $.30^{* * *}$ & $-.17 * *$ & $-.21 * * *$ & & & & & & & & \\
\hline Epist. Beliefs (Certain) & 5.2 & 0.7 & -.10 & $.39 * * *$ & $.67^{* * *}$ & $-.38 * * *$ & & & & & & & \\
\hline Epist. Beliefs (Justif) & 2.8 & 1.1 & $.40 * * *$ & $-.20 * *$ & -.02 & $.65 * * *$ & $-.20 * *$ & & & & & & \\
\hline Task Goal & 4.2 & 1.2 & $.46 * * *$ & $-.30 * * *$ & .06 & $.30 * * *$ & -.03 & $.50 * * *$ & & & & & \\
\hline Perf. Approach Goal & 4.2 & 1.2 & $.13 *$ & .06 & $.19 * *$ & $.14 *$ & $.14 *$ & $.23 * * *$ & $.21 * *$ & & & & \\
\hline Perf. Avoid Goal & 3.2 & 1.2 & $-.18 * *$ & $.41 * * *$ & $.30 * * *$ & $-.15 * *$ & $.41 * * *$ & $-.17 * * *$ & $-.24 * * *$ & $.26 * * *$ & & & \\
\hline Self-Efficacy & 4.8 & 1.3 & $.39 * * *$ & $-.31 * * *$ & -.09 & $.31 * * *$ & $-.22 * * *$ & $.39 * * *$ & $.41 * * *$ & .06 & $-.24 * * *$ & & \\
\hline SE for Self-Reg & 4.4 & 1.0 & $.41 * * *$ & $-.26 * * *$ & .02 & $.24 * * *$ & -.05 & $.39 * * *$ & $.61 * * *$ & $.11 *$ & $-.27 * * *$ & $.57 * * *$ & \\
\hline Final Grade & 81.9 & 11.5 & $.29 * * *$ & $-.31 * * *$ & $-.21 * * *$ & $.35 * * *$ & $-.36^{* * *}$ & $.33 * * *$ & $.28 * * *$ & .10 & $-.29 * * *$ & $.55 * * *$ & $.39 * * *$ \\
\hline
\end{tabular}

Note. $\quad * p<.05 . \quad * * p<.01 . \quad * * * p<.0001$




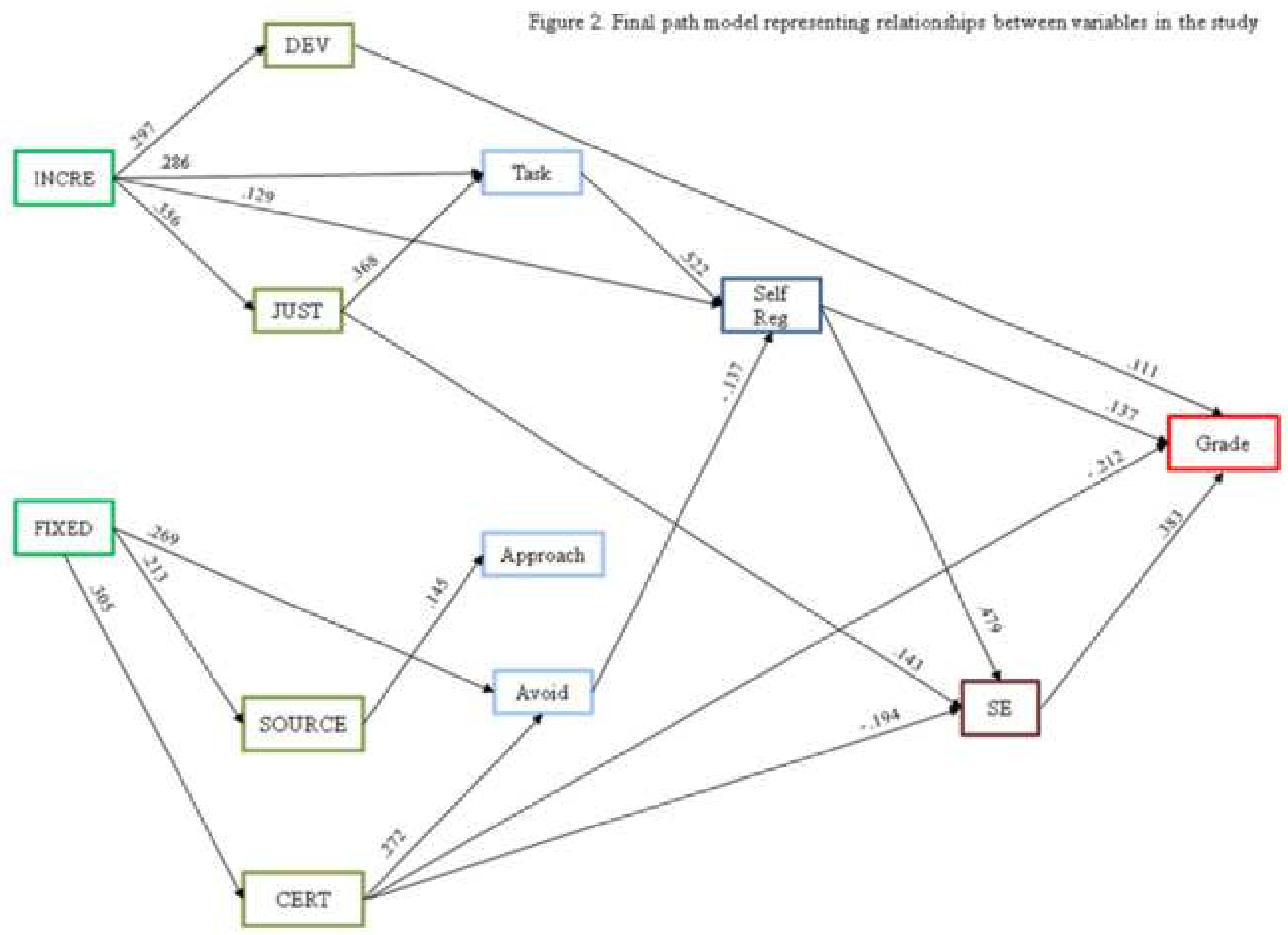


Table 3

Decomposition of Effects From the Path Analysis

\begin{tabular}{|c|c|c|c|c|}
\hline Effects & $\begin{array}{l}\text { Parameter } \\
\text { Estimate }\end{array}$ & $\begin{array}{c}\text { Standardized } \\
\text { estimate } \\
(\beta)\end{array}$ & $\mathrm{t}$ & $\mathrm{R}^{2}$ \\
\hline On Epist. Beliefs (Development) & & & & .09 \\
\hline of Incremental Theory & .196 & .297 & 7.39 & \\
\hline On Epist. Beliefs (Justification) & & & & .13 \\
\hline of Incremental Theory & .205 & .356 & 8.76 & \\
\hline On Epist. Beliefs (Source) & & & & .05 \\
\hline of Fixed Theory & .163 & .213 & 5.03 & \\
\hline On Epist. Beliefs (Certainty) & & & & .09 \\
\hline of Fixed Theory & .243 & .305 & 7.59 & \\
\hline On Task Goal & & & & .29 \\
\hline of Epist. Beliefs (Justification) & .626 & .368 & 9.39 & \\
\hline of Incremental Theory & .280 & .286 & 7.28 & \\
\hline On Perf-Approach Goal & & & & .02 \\
\hline of Epist. Beliefs (Source) & .175 & .145 & 3.35 & \\
\hline On Perf-Avoid Goal & & & & .19 \\
\hline of Epist. Beliefs (Certainty) & .321 & .272 & 6.69 & \\
\hline of Fixed Theory & .253 & .269 & 6.65 & \\
\hline On SE for Self-Regulation & & & & .40 \\
\hline of Task Goal & .436 & .522 & 13.6 & \\
\hline of Perf-Avoid Goal & -.109 & -.137 & -3.85 & \\
\hline of Incremental Theory & .106 & .129 & 3.39 & \\
\hline On Self-Efficacy & & & & .37 \\
\hline of SE for Self-Regulation & .616 & .479 & 12.9 & \\
\hline of Epist. Beliefs (Certainty) & -.234 & -.194 & -5.33 & \\
\hline of Epist. Beliefs (Justification) & .262 & .143 & 3.78 & \\
\hline On Final Grade & & & & .38 \\
\hline of Self-Efficacy & 3.31 & .383 & 8.78 & \\
\hline of SE for Self-Regulation & 1.53 & .137 & 3.26 & \\
\hline of Epist. Beliefs (Certainty) & -2.20 & -.212 & -5.44 & \\
\hline of Epist. Beliefs (Development) & 1.53 & .111 & 2.86 & \\
\hline
\end{tabular}

Note. $\mathrm{N}=508$ 
Table 4. Direct and Indirect Effects on Science Achievement

\begin{tabular}{lrrrrr}
\hline \multicolumn{1}{c}{ Effect } & $r$ & Direct & Indirect & Total & Noncausal \\
\hline On Final Grade & & & & & \\
of Self-Efficacy & $.55^{*}$ & .383 & .000 & .383 & .167 \\
of SE for Self-Regulation & $.39^{*}$ & .137 & .183 & .320 & .070 \\
of Perf-Avoid Goal & $-.29^{*}$ & .000 & -.044 & -.044 & -.246 \\
of Perf-Approach Goal & .10 & .000 & .000 & .000 & .101 \\
of Task Goal & $.28^{*}$ & .000 & .168 & .168 & .112 \\
of Epist. Beliefs (Certainty) & $-.36^{*}$ & -.212 & -.086 & -.298 & -.070 \\
of Epist. Beliefs (Source) & $-.21^{*}$ & .000 & .000 & .000 & -.210 \\
of Epist. Beliefs (Justification) & $.33^{*}$ & .000 & .081 & .081 & .249 \\
of Epist. Beliefs (Development) & $.35^{*}$ & .111 & .000 & .111 & .239 \\
of Incremental Theory & $.29^{*}$ & .000 & .163 & .163 & .130 \\
of Fixed Theory & $-.31^{*}$ & .000 & -.104 & -.104 & -.206 \\
\hline
\end{tabular}

$* p<.05$ 
Table 5. Means and Standard Deviations for Variables in the Study by Gender and Race/Ethnicity

\begin{tabular}{|c|c|c|c|c|c|c|c|c|c|c|c|c|}
\hline \multirow[b]{3}{*}{ Variables } & \multicolumn{4}{|c|}{ GENDER } & \multicolumn{8}{|c|}{ RACE/ETHNICITY } \\
\hline & \multicolumn{2}{|c|}{ Girls } & \multicolumn{2}{|c|}{ Boys } & \multicolumn{2}{|c|}{$\begin{array}{c}\text { African } \\
\text { American }\end{array}$} & \multicolumn{2}{|l|}{ White } & \multicolumn{2}{|l|}{ Asian } & \multicolumn{2}{|l|}{ Hispanic } \\
\hline & $\mathrm{M}$ & $\mathrm{SD}$ & $\mathrm{M}$ & $\mathrm{SD}$ & $\mathrm{M}$ & $\mathrm{SD}$ & $\mathrm{M}$ & SD & $\mathrm{M}$ & $\mathrm{SD}$ & $\mathrm{M}$ & SD \\
\hline Fixed Theory of Ability & 3.0 & 1.3 & 2.8 & 1.3 & 2.8 & 1.3 & 2.9 & 1.3 & 2.9 & 1.3 & 3.2 & 1.3 \\
\hline Incremental Theory of Ability & $4.5 \mathrm{a}$ & 1.2 & $4.8 \mathrm{~b}$ & 1.1 & 4.5 & 1.0 & 4.4 & 1.1 & 4.4 & 1.1 & 4.2 & 0.9 \\
\hline Epist. Beliefs (Justification) & 5.2 & 0.6 & 5.1 & 0.7 & 5.2 & 0.6 & 5.2 & 0.7 & 5.1 & 0.7 & 5.1 & 0.7 \\
\hline Epist. Beliefs (Development) & 5.1 & 0.7 & 5.1 & 0.8 & 5.1 & 0.8 & 5.2 & 0.7 & 5.0 & 0.8 & 5.0 & 0.9 \\
\hline Epist. Beliefs (Source) & 3.1 & 1.0 & 3.0 & 1.0 & 3.0b & 1.1 & $2.9 \mathrm{~b}$ & 0.9 & $3.3 \mathrm{a}$ & 0.8 & 3.3a & 1.0 \\
\hline Epist. Beliefs (Certainty) & 2.8 & 1.0 & 2.8 & 1.0 & $2.9 \mathrm{~b}$ & 1.2 & $2.6 \mathrm{c}$ & 1.0 & $2.9 \mathrm{~b}$ & 0.8 & 3.3a & 1.1 \\
\hline Task Goals & 4.1 & 1.3 & 4.3 & 1.3 & 4.2 & 1.2 & 4.2 & 1.2 & 4.2 & 1.3 & 4.4 & 1.0 \\
\hline Performance Approach Goals & 4.2 & 1.4 & 4.3 & 1.2 & 4.2 & 1.4 & 4.2 & 1.1 & 4.4 & 1.2 & 4.1 & 1.3 \\
\hline Performance Avoid Goals & 3.1 & 1.4 & 3.2 & 1.3 & 3.2 & 1.3 & 3.1 & 1.2 & 3.2 & 1.1 & 2.9 & 1.2 \\
\hline Self-Efficacy & 4.8 & 1.4 & 4.9 & 1.1 & 4.8 & 1.4 & 4.9 & 1.1 & 4.9 & 1.1 & 4.6 & 1.5 \\
\hline SE for Self-Regulation & 4.4 & 1.1 & 4.5 & 1.0 & 4.6 & 1.1 & 4.4 & 0.9 & 4.5 & 0.8 & 4.5 & 1.1 \\
\hline Achievement & 83.4 & 11.0 & 82.7 & 11.9 & $82.5 \mathrm{~b}$ & 9.4 & 83.6ab & 10.5 & 84.3a & 8.5 & 79.1c & 12.0 \\
\hline
\end{tabular}

Note. Mean scores for academic achievement are based on a 100-point grading scale. All other variable means range from 1 (low) to 6 (high).

Race/ethnicity means for a dependent variable (row) that are subscripted by different letters and in bold are statistically different (experiment-wise $\alpha$ $<.05)$ computed on an effect identified by ANCOVA. Mean scores for the ANCOVA analyses were adjusted for previous achievement. Gender mean differences were computed using t-test analysis. Boys $(\mathrm{n}=297)$, Girls $(\mathrm{n}=211)$. White $(\mathrm{n}=242)$, African American $(\mathrm{n}=83)$, Asian $(\mathrm{n}=97)$, Hispanic $(\mathrm{n}=51)$. 